\title{
Penerapan Model Pembelajaran NHT melalui Lesson Study untuk Meningkatkan Pemahaman Konsep dan Kemampuan Mengemukakan Pendapat Mahasiswa pada Matakuliah Biologi Umum
}

\author{
Nugroho Aji Prasetiyo, Zuni Mitasari \\ Program Studi Pendidikan Biologi, FIP, Universitas Tribhuwana Tunggadewi, \\ Jl. Telaga Warna Tlogomas, Malang, 65 I44 Indonesia
}

\begin{abstract}
ABSTRAK
Penelitian ini bertujuan meningkatkan pemahaman konsep dan kemampuan mengemukakan pendapat mahasiswa yang menempuh matakuliah biologi umum dengan menerapkan model pembelajaran Number Head Together (NHT) NHT melalui Lesson study (LS). Penelitian ini menggunakan pendekatan deskriptif kualitatif. Jenis penelitian ini adalah penelitian tindakan kelas yang ditempuh dengan tujuan untuk memperbaiki praktik pembelajaran secara nyata di dalam kelas. Penelitian tindakan kelas ini dilaksanakan dalam tiga siklus. Setiap siklus terdiri atas empat tahap, yaitu: perencanaan (planning), pelaksanaan tindakan (action), pengamatan tindakan (observation) dan refleksi (reflection), pada setiap pertemuan menerapkan tahapan LS, yaitu plan, do, dan see. Berdasarkan hasil analisis data nilai pemahaman konsep mahasiswa meningkat dari siklus I ke siklus III, yaitu $70,74 \%$ pada siklus I, $80 \%$ pada siklus II dan $81,3 \%$ pada siklus III. Hasil analisis data menunjukkan bahwa kemampuan mengemukakan pendapat mahasiswa meningkat dari siklus I hingga siklus III. Pada siklus I jumlah persentase nilai kemampuan mengemukakan pendapat mahasiswa sebesar 80,63\%, meningkat menjadi $87,7 \%$ pada siklus II, dan sebesar $87,85 \%$ pada siklus III. Model pembelajaran NHT melalui LS mampu meningkatkan pemahaman konsep dan kemampuan mengemukakan pendapat mahasiswa
\end{abstract}

Kata kunci: NHT, LS, pemahaman konsep, kemampuan mengemukakan pendapat

\section{Pendahuluan}

Hasil belajar siswa diukur dari tiga ranah penilaian yaitu kognitif, psikomotor, dan afektif. Penilaian kognitif salah satunya menilai pemahaman konsep yang diperoleh siswa selama proses belajar mengajar. Pemahaman konsep merupakan kemampuan untuk menerjemahkan, menginterpretasi, mengekstrapolasi, dan menghubungkan antara fakta atau konsep. Setelah memahami suatu konsep peserta didik dapat memanfaatkan isinya dan mampu menghubungkan dengan hal-hal yang lain. Seorang peserta didik dikatakan memahami sesuatu apabila peserta didik dapat memberikan penjelasan atau memberi uraian yang lebih rinci tentang hal itu dengan menggunakan kata-kata sendiri (Munafiah, 20II). Selain pemahaman konsepkonsep dalam pembelajaran, keberhasilan proses belajar mengajar salah satunya ditentukan oleh kemampuan verbal peserta didik. Bahasa merupakan salah satu alat untuk berkomunikasi dalam kehidupan manusia. Oleh karena itu, pembelajaran bahasa lebih diarahkan untuk meningkatkan kemampuan peserta didik berkomunikasi baik secara lisan maupun tulisan. Dikatakan demikian karena dengan bahasa peserta didik saling berhubungan (berkomunikasi). Dengan berkomunikasi ini peserta didikdapat saling berbagi pengalaman dan dapat meningkatkan kemampuannya. Disamping itu juga peserta didik sangat dituntut untuk mampu mengemukakan pendapat, ide, gagasan maupun pengalaman serta perasaannya secara lisan dan tulisan dengan dengan baik dan benar.

Kemampuan mengemukakan pendapat adalah kemampuan menyampaikan gagasan atau pikiran secara lisan yang logis, tanpa memaksakan kehendak sendiri serta menggunakan bahasa yang baik. Kemampuan seseorang mengungkapkan pendapat sangat berkaitan dengan kepribadian individu, dimana kepribadian seseorang berhubungan dengan hal yang ditangkap /direspon oleh orang lain berdasarkan pengalaman dan pengetahuanyang dimiliki, karena hal yang diungkapkan amat sangat menentukan tafsiran orang lain terhadap kepribadian seorang individu. Dalam suatu diskusi pendapat yang baik dapat membentuk saling pengertian, 
menumbuhkan persahabatan, menyebarluaskan pengetahuan (Anindawati, 2013).

Ditemukan permasalahan pada kemampuan mahasiswa dalam menguasai konsep-konsep pembelajaran kurang, terbukti pada saat melakukan presentasi maupun umpan balik pada dosen mahasiswa hanya mampu membaca informasi yang diperolehnya dari sumber belajar tanpa mengolah dan memahami informasi tersebut, sumber belajar yang mereka gunakan masih terbatas pada buku teks biologi SMA, artikel dari internet dan lembar kerja siswa (LKS) biologi SMA akibatnya terjadi banyak miskonsepsi terkait konsepkonsep penting yang harus dipahami mahasiswa. Di akhir pembelajaran dosen pengampu memberikan konfirmasi dan penguatan terhadap konsep-konsep yang dipelajari, walaupun tidak semua konsep dibahas hanya konsep yang ditanyakan mahasiswa. Dosen pengampu menggunakan metode presentasi diskusi dengan membentuk kelompok, yaitu kelompok penyaji yang bertugas menyajikan resume topik yang dipelajari, kelompok pembahas yang bertugas menambahkan atau menyanggah informasi, serta peserta diskusi. Hal ini seharusnya sudah memfasilitasi mahasiswa untuk berpendapat, tetapi berdasarkan hasil pengamatan selama pembelajaran berlangsung hanya beberapa mahasiswa yang menggunakan kesempatannya untuk berpendapat. Permasalahan-permasalahan pembelajaran tersebut lebih mengarah pada rendahnya kemampuan siswa dalam mengemukakan pendapat yang ditunjukkan dengan rendahnya kemampuan bertanya, menjawab, memberikan pernyataan dan tanggapan. Berdasarkan hasil pengamatan tersebut, diperlukan suatu pemecahan yang dapat meningkatkan kemampuan mengemukakan pendapat mahasiswa. Kemampuan ini merupakan suatu keterampilan yang perlu dikembangkan dalam diri mahasiswa agar bermanfaat untuk dirinya di masa yang akan datang. Selain itu permasalahan rendahnya pemahaman konsep juga muncul dan menjadi permasalahan dalam proses pembelajaran matakuliah biologi umum untuk kimia.

Sehubungan dengan permasalahan di atas, maka dapat ditegaskan bahwa usaha perbaikan proses pembelajaranmelalui upaya pemilihan model pembelajaran yang tepat dan inovatif dalam pembelajaran biologi merupakan suatu kebutuhan yang sangat penting untuk dilakukan. Menurut Arends (2007) model pembelajaran kooperatif dikembangkan untuk mencapai minimal tiga tujuan instruksional penting yaitu meningkatkan kemampuan akademik, sikap toleransi dan menerima perbedaan, dan kemampuan sosial. Salah satu model pembelajaran yang dapat digunakan untuk memperbaiki kualitas kemampuan berpikir siswa dan hasil belajar adalah model pembelajaran Numbered Head Together (NHT) melalui Lesson Study (LS). Berdasarkan fakta di lapangan, model pembelajaran Numbered Head Together (NHT) melalui Lesson Study (LS) belum pernah diterapkan oleh dosen pengampu matakuliah biologi untuk kimia.

Berdasarkan penelitian Silangit (2012), penggunaan model kooperatif tipe NHT mampu meningkatkan kemampuan mengemukakan pendapat siswa Pada Pelajaran Bahasa Indonesia, selanjutnya penelitian tindakan kelas Sahara (2012) menunjukkan hasil model pembelajaran kooperatif NHT mampu meningkatkan pemahaman konsep peserta didik pada mata pelajaran matematika. Berdasarkan hal tersebut, perlu dilakukan Penelitian penerapan model pembelajaran NHT melalui LS untuk meningkatkan pemahaman konsep dan kemampuan mengemukakan pendapat mahasiswa pada matakuliah biologi umum.

\section{Metode Penelitian}

Penelitian ini menggunakan pendekatan deskriptif kualitatif. Jenis penelitian ini adalah penelitian tindakan kelas yang ditempuh dengan tujuan untuk memperbaiki praktek pembelajaran secara nyata di dalam kelas. Penelitian tindakan kelas ini dilaksanakan dalam tiga siklus. Setiap siklus terdiri atas empat tahap, yaitu: perencanaan (planning), pelaksanaan tindakan (action), pengamatan tindakan (observation) dan refleksi (reflection). Pada setiap pertemuan menerapkan tahapan LS, yaitu plan, do, dan see. Teknik pengumpulan data dilaukan dengan tenik observasi, lembar kerja, wawancara, catatan lapangan dan dokumentasi (foto dan video). Instrumen penelitian yang digunakan dalam penelitian ini adalah: I) Lembar observasi keterlaksanaan pembelajaran oleh observer digunaan untuk mengambil data keterlaksanaan pembelajaran menggunakan model NHT melaui LS; 2) Lembar kerja mahasiswa (LKM) digunakan untuk mengambil data pemahaman konsep mahasiswa; dan 3) Lembar penilaian kemampuan mengemukakan pendapat mahasiswa digunakan untu mengambil data kemampuan mengemukakan pendapat mahasiswa. Selanjutnya data yang diperoleh dianalisis data secara kualititatif dengan model analisis interaktif yang terdiri atas reduksi data, paparan data dan penarikan kesimpulan.

Tingkat keberhasilan penelitian tindakan oleh dosen diukur melalui persentase keterlaksanaan tindakan. Data hasil pemahaman konsep mahasiswa diukur melalui LKM yang akan dianalisis berdasarkan persentase pemahaman konsep. Kemampuan mengemukakan pendapat mahasiswa diukur dengan persentase capaian penilaian kemampuan mengemukakan pendapat. Keseluruhan data yang sudah dianalisis kemudian dievaluasi dan dilanjutkan dengan refleksi.

\section{Hasil dan Pembahasan}

Berdasarkan hasil analisis data nilai pemahaman konsep mahasiswa meningkat dari siklus I ke siklus III, yaitu $70,74 \%$ pada siklus I, $80 \%$ pada siklus II dan $81,3 \%$ pada siklus III. Hasil analisis data menunjukkan bahwa kemampuan mengemukakan pendapat mahasiswa 
meningkat dari siklus I hingga siklus III. Pada siklus I persentase nilai kemampuan mengemukakan pendapat mahasiswa sebesar $80,63 \%$, meningkat menjadi $87,7 \%$ pada siklus II, dan sebesar $87,85 \%$ pada siklus III. Ringkasan peningkatan hasil penilaian pemahaman konsep dan kemampuan mengemukakan pendapat mahasiwa dapat dilihat pada Tabel I.

Tabel I. Perbandingan Hasil Penilaian Pemahaman Berpikir Kreatif

\begin{tabular}{cll}
\hline & $\begin{array}{l}\text { Presentase } \\
\text { Tindakan }\end{array}$ & $\begin{array}{l}\text { Persentase } \\
\text { Kemampuan } \\
\end{array}$ \\
& $\begin{array}{c}\text { Kemahaman } \\
\text { Mahasiswa (\%) }\end{array}$ & $\begin{array}{l}\text { Mengemukakan } \\
\text { pendapat } \\
\text { Mahasiswa (\%) }\end{array}$ \\
\hline Siklus I & 70,74 & 80,63 \\
Siklus II & 80 & 87,7 \\
Siklus III & 81,3 & 87,85 \\
\hline
\end{tabular}

Hasil analisis data menunjukkan bahwa rata-rata persentase keterlaksanaan kegiatan pembelajaran yang dilakukan selama siklus I sampai siklus 3 adalah I00\% yang termasuk dalam kategori sangatberhasil. Peningkatan keterlaksanaan pembelajaran selama tiga siklus disebabkan karena pada setiap pertemuan, dosen model selalu mengadakan diskusi perencanaan pembelajaran dan di akhir kegiatan pembelajaran selalu mengadakan kegiatan refleksi bersama tim LS. Lesson Study merupakan kegiatan pengkajian pembelajaran yang dilaksanakan secara kolaboratif oleh sekelompok guru untuk meningkatkan kualitas pembelajaran secara bertahap dan berkelanjutan (Ibrohim, 20II). Kegiatan yang dilakukan sekelompok guru dalam LS yaitu mengidentifikasi masalah pembelajaran, merancang suatu skenario pembelajaran, membelajarkan siswa sesuai skenario, mengevaluasi skenario pembelajaran, merevisi skenario pembelajaran, membelajarkan lagi skenario yang telah direvisi, dan mengevaluasi lagi pembelajaran serta membagikan hasilnya dengan guru-guru lain (Susilo, 20II).

Berdasarkan hasil analisis data mahasiswa sudah mengalami peningkatan pemahaman konsep dari siklus I ke siklus III. Sebelum dilakukan penerapan model pembelajaran NHT, pemahaman konsep mahasiswa hanya terbatas pada informasi pada buku-buku SMA (masih terbawa kebiasaaan sekolah menengah (book oriented)) dan sulit untuk memilih konsep esensi dari suatu materi. Setelah dilakukan penerapan model pembelajaran NHT dalam tiga siklus mahasiswa mengalami peningkatan pemahaman konsep ditunjukkan dengan peningkatan nilai persentase pemahaman konsep. Mahasiswa saat pembelajaran juga menunjukkan indikator-indikator pemahaman konsep menurut Arvianto, Ilham Haris, dkk, (20II) meliputi hal-hal berikut: I) Menyatakan ulang sebuah konsep. 2) Mengklasifikasikan obyek-obyek menurut sifat-sifat tertentu (sesuai dengan konsepnya). 3) Memberi contoh dan non contoh dari konsep 4) Menyajikan konsep dalam berbagai bentuk representasi matematis 5.) Mengembangkan syarat perlu dan syarat cukup suatu konsep. 6) Menggunakan, memanfaatkan, dan memilih prosedur atau operasi tertentu 7) Mengaplikasikan konsep dalam pemecahan masalah.

Berdasarkan hasil analisis data mahasiswa sudah mengalami peningkatan kemampuan mengemukakan pendapat dari siklus I ke siklus III. Hal ini ditunjukkan dengan perolehan skor maksimal pada aspek-aspek dalam rubrik penilaian kemampuan mengemukakan pendapat. Menurut Anindawati (2013) aspek-aspek kemampuan mengemukakan pendapat, adalah: I) Menyampaikan gagasan atau pikiran secara lisan yang logis, 2) Tanpa memaksakan kehendak sendiri, 3) Menggunakan bahasa yang baik. Parera (2010) mengemukakan bahwa untuk dapat mengutarakan pendapat dengan jelas sehingga mudah dimengerti, orang perlu belajar dan melatih diri menggunakan kata-kata yang tepat dan menyusunnya menjadi kalimat yang baik di samping harus dapat pula mengutarakan gagasan itu dalam urutan yang logis.

\section{Simpulan}

Kegiatan Lesson Study dapat meningkatkan kualitas pembelajaran setiap pertemuan dalam setiap siklus dan menunjukkan persentase keterlaksanaan pembelajaran siklus I, II dan III sebanyak I00\%. Penerapan model pembelajaran NHT berbasis LS dapat meningkatkan pemahaman konsep dan kemampuan mengemukakan pendapatmahasiswa.

Penelitian Tindakan Kelas (PTK) melalui kegiatan LS perlu dikembangkan oleh para dosen karena sangat bermanfaat untuk meningkatkan kemampuan dosen dalam mengajar, meningkatkan profesionalisme dosen dan kualitas pembelajaran, serta memberikan kesempatan kepada seluruh peserta didik untuk dapat mengikuti proses pembelajaran dengan baik.

\section{Daftar Pustaka}

Anindawati, H.D. 2013. Teknik Permainan Untuk Meningkatkan Kemampuan Mengemukakan Pendapat Siswa [online] http://jurnal.fkip.uns.ac.id/index.php/counsilium/arti cle/download/3266/229Diakses pada tanggal I7 Maret 2016

Arends, R. I. 2007. Learning to Teach. Yogyakarta: Pustaka Belajar.

Ibrohim. 2010. Paduan Pelaksanaan Lesson Study di KKG. Malang:Universitas Negeri Malang

Munafiah, S. 20I I. Peningkatan Pemahaman Konsep Peserta Didik Pada Materi Hukum Newton dengan Menggunakan Media Pembelajaran Visual Berbasis Macromedia Flash Kelas X-I MA AL Ahrom Karangsari Karangtengah Demak Tahun Pelajaran $2011 / 2012$

[online] http://library.walisongo.ac.id/digilib/downloa d.php?id=20972Diakses pada tanggal I7 Maret 2016 
Parera, J.D. 20I0. Belajar Mengemukakan Pendapat. Jakarta: Erlangga.

Sahara, N. 2012. Meningkatkan prestasi belajar matematika siswa kelas VIIISMP Negeri I Batuatas pada pokok bahasan sistem persamaan linear dua peubah melalui model pembelajaran kooperatif tipe NHT[online] http://pendidikanmatematika.files.com/2009/03/koo peratif_tipe_nht.docDiakses pada tanggal I7 Maret 2016

Silangit, E. P. 2012 Meningkatkan Kemampuan Mengemukakan Pendapat Siswa Kelas V Melalui Metode Kooperatif Tipe NHT Pada Pelajaran Bahasa Indonesia Di SD Swasta Nusantara Lubuk Pakam[online]

http://digilib.unimed.ac.id/public/UNIMED-

Undergraduate-30358BAB\%20I.pdf

Diakses pada tanggal I7 Maret 2016

Susilo, dkk. 20I I. Lesson Study Berbasis Sekolah. Malang:

Bayumedia Publishing 